\title{
Challenges in Responding \\ to a Sustained, Continuing Volcanic \\ Crisis: The Case of Popocatépetl \\ Volcano, Mexico, 1994-Present
}

\author{
Servando De la Cruz-Reyna, Robert I. Tilling \\ and Carlos Valdés-González
}

\begin{abstract}
Popocatépetl Volcano, located in the central Trans-Mexican Volcanic Belt, is surrounded by a densely populated region with more than 20 million people. During the past 23,000 years, this volcano has produced eruptions ranging widely in size and style, including Plinian events and massive sector collapses. However, the historical activity of Popocatépetl, recorded in detail since 1500 , consists of only nineteen small to moderate eruptions, several similar in style to the current eruptive episode (1994-present). After nearly 70 years of quiescence since its eruptions in the mid-1920s, Popocatépetl reawakened in December 21, 1994. This eruptive activity, which is still ongoing, has been characterized by a succession of lava dome growth-and-destruction episodes: pulses of effusive and moderately explosive activity alternating with periods of almost total quiescence. This pattern appears to be characteristic of all historical eruptions, several of which lasted for decades, with interspersed lull periods that in some cases make it difficult to identify the end of the eruptive episodes. In this chapter, we discuss the problems and challenges posed by a prolonged, low-level volcanic crisis (or "semi-crisis") of variable intensity that has lasted for more than 20 years, without showing any signs of coming to an end. Paradoxically, this still-continuing crisis has spawned two opposite developments: (1) during periods of little visible activity, people dwelling near the volcano become somewhat
\end{abstract}

S. De la Cruz-Reyna ( $\square)$

Instituto de Geofísica, Universidad Nacional

Autónoma de México UNAM, CDMX, Mexico

e-mail: sdelacruzr@gmail.com

R.I. Tilling

Volcano Science Center, U.S. Geological Survey,

Menlo Park, USA

C. Valdés-González

Centro Nacional de Prevención de Desastres

CENAPRED, CDMX, Mexico

Advs in Volcanology (2018) 235-252

https://doi.org/10.1007/11157_2016_37

(C) The Author(s) 2017

Published Online: 15 March 2017 
apathetic and indifferent; but (2) during times of easily observed visible activity, awareness of changes at the volcano-and their hazardous implications - is rapidly and greatly enhanced by the common use of social media by people.

\section{Introduction}

Disasters can occur when society fails to identify and foresee the potentially hazardous manifestations of a natural phenomenon. However, disasters may also occur if society fails to adopt adequate measures to reduce the risks - to people, property, and infrastructure - posed by hazardous phenomena even if recognized in advance. Responding effectively to hazards is a process as complex as is the fabric of society itself, as each hazardous phenomenon has a variety of destructive manifestations, and each may affect different sectors of society in particular ways. This is especially true when dealing with volcanic crises. As has been long recognized (e.g., Fiske 1984; Peterson 1986, 1988; Tilling 1989; Voight 1990; Peterson and Tilling 1993; Haynes et al. 2008; Solana et al. 2008; Fearnley 2013), the process of crisis response entails close interaction between three main entities: (1) The scientists studying the hazardous phenomena and their potential social outcomes; (2) the authorities in charge of public safety and infrastructure; and (3) the affected populace. The wide spectrum of backgrounds and attitudes of all the involved stakeholders during such interaction, together with the vague or imprecise information generally available during the crisis, often combine to hinder effective communications among the entities involved. Poor communications in turn complicate the perception of the risk, a factor likely to increase societal vulnerability. Thus, during an evolving crisis, it is critical to develop a perception of risk as uniform as possible among all stakeholders - no easy task when the affected population is measured in millions. To achieve this goal requires searching for communication tools that can describe-as simply as possible - the relations between the level of threat posed by the volcano, and the level of response of the authorities and the affected public. In the case of Popocatépetl, the Civil Protection of Mexico addressed this challenge by developing and implementing the Volcanic Traffic Light Alert System (VTLAS). Distinct from other volcano alert systems (VALs) - typically referenced to the activity of the volcanoused to communicate warning information from scientists to civil authorities managing volcanic hazards (Fearnley 2013; Potter et al. 2014), the VTLAS scheme (discussed in detail below) additionally was intended to reduce the possibility of ambiguous interpretations of intermediate alert levels by the large populations at risk. This additional component marks a significant advance in the management of volcanic crises in Mexico (De la Cruz-Reyna and Tilling 2008).

Before proceeding further, we should summarize how risk is managed by the National Civil Protection System of México (SINAPROC), which was created in 1986 after the catastrophic disaster caused by a M 8.1 earthquake on September 19, 1985. The executive body of the SINAPROC at the federal level is the General Coordination, housed within the Ministry of the Interior (Secretaría de Gobernación). The General Coordination is supported by four agencies: (1) the National Direction of Civil Protection, an operational body in charge of implementing the preventive and relief actions; (2) the General Direction of Integral Risk Management, which provides the funding for prevention and emergency actions; (3) the General Direction of Interlinking and Regulations, which coordinates the different government levels involved with civil protection; and (4) the National Center for Disaster Prevention (CENAPRED), a technical 
body created in September 19, 1988, with substantial technical and generous financial support from the government of Japan. The mission of CENAPRED is to promote the applications of science and technology for the prevention and mitigation of disasters, to train and inform professionals and technicians on these subjects, and to disseminate the necessary information for preparedness and self-protection.

CENAPRED also acts as an active interface between the operative, decision-making authorities of the SINAPROC and the academic scientific community. In conducting its work, CENAPRED utilizes four advisory scientific committees on topics relevant for disaster prevention, composed of prominent, experienced Mexican scientists in the areas of Earth sciences, hydro-meteorological sciences, social sciences, and chemical and industrial hazards. There are also ad-hoc sub-committees, as is the case of the Advisory Committee for Popocatépetl Volcano, on which several international volcanologistsespecially from the U.S. Geological Survey
(USGS) — have actively participated. This advisory sub-committee will be herein referred as the Popocatépetl Scientific Committee (PSC).

Popocatépetl has remained persistently active for over 20 years, thereby creating a long-standing volcanic crisis that has imposed additional difficulties in the management of the volcanic risk. CENAPRED has been and remains in charge of the monitoring of Popocatépetl volcano, and it also continues to host and coordinate PSC sessions as needed.

\section{Popocatépetl Volcano: Geologic Setting and Eruptive History}

Popocatépetl Volcano $\left(19.02^{\circ} \mathrm{N}, \quad 98.62^{\circ} \mathrm{W}\right)$, which lies within the central Trans-Mexican Volcanic Belt (Fig. 1), is located about $60 \mathrm{~km}$ SE of México City and $45 \mathrm{~km}$ W of Puebla City.

These two populations centers, combined with other nearby cities within a $100-\mathrm{km}$ radius around the volcano, contain a total population of

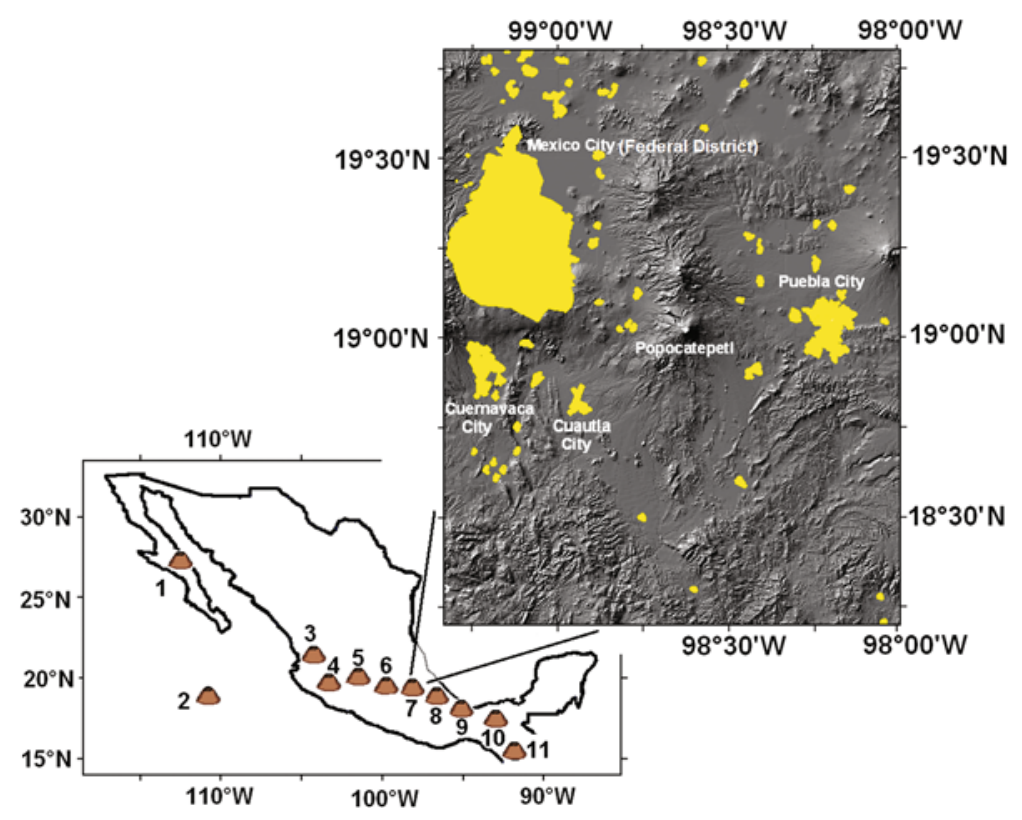

Fig. 1 Sketch map showing the location of Popocatépetl Volcano and other historically active volcanoes of Mexico: 1 Tres Vírgenes; 2 Evermann (Socorro); 3 Ceboruco; 4 Colima; 5 Parícutin; 6 Xitle; 7 Popocatépetl; 8 Pico de Orizaba (Citlaltépetl); 9 San Martín Tuxtla;
10 El Chichón; 11 Tacaná. The inset shows the distribution of cities and major towns (yellow) within $100 \mathrm{~km}$ of Popocatépetl's active crater. The cities of Mexico City, Puebla, Cuernavaca, Cuautla and others located within the inset have a combined population over 20 million 

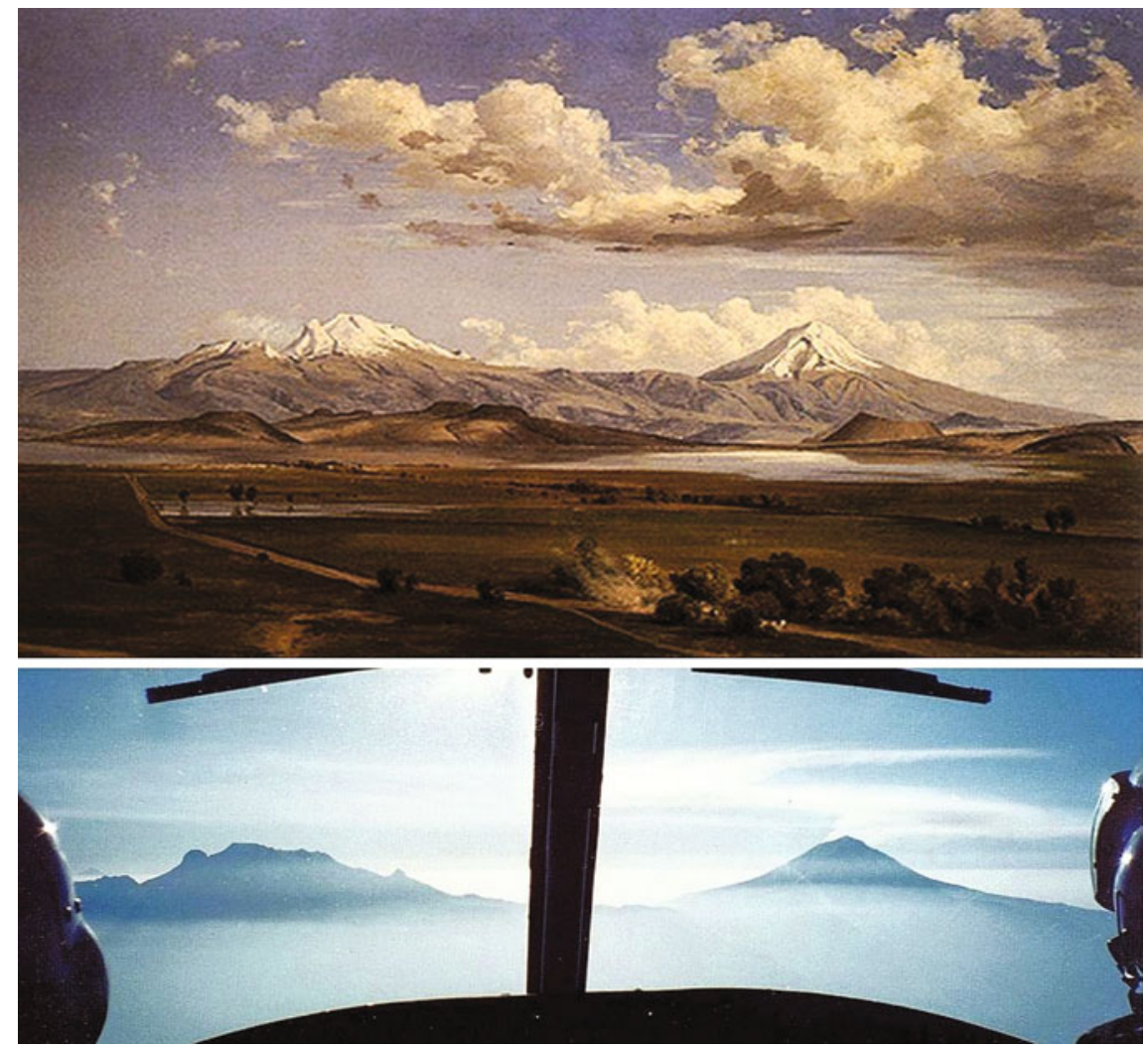

Fig. 2 Popocatépetl (right) and Iztaccíhuatl Volcanoes: Above, "Camino a Chalco con los volcanes" painting by José María Velasco, 1891 (Museo Nacional de Arte,
MUNAL, Mexico). Below, view of these two prominent peaks through helicopter windshield (Photograph by S. De la Cruz-Reyna in September 2002) over 20 million people. Rising 5454 meters above sea level, the conical volcanic edifice of Popocatépetl is topped by a $600 \times 800 \mathrm{~m}$ elliptical summit crater. Popocatépetl is the youngest peak within the Sierra Nevada, a volcanic mountain range which extends in a roughly $\mathrm{N}-\mathrm{S}$ direction. To the north of Popocatépetl, the volcanic complex Iztaccíhuatl complements the iconic volcanic landscape of the region (Fig. 2).

Geological evidence indicates that a large eruption about 23,000 years destroyed a pre-existing volcanic edifice, generating massive debris avalanches (Robin and Boudal 1987; Boudal and Robin 1989; Siebe et al. 1995). Since then, Popocatépetl's eruptive history has been characterized by at least seven major explosive eruptions and many smaller eruptions that have produced large volumes of ash and pumice. Three of the most recent explosive eruptions (ca. $3000 \mathrm{~B}$. C., between 800 and 200 B.C., and ca. A.D. 800) affected human settlements, as indicated by archaeological remains buried by ashfall deposits and pottery shards incorporated by mudflows (Siebe et al. 1996; Siebe and Macías 2004). After the last of these major eruptions, activity at Popocatépetl has remained moderate for nearly 1200 years. Batches of magma were extruded, producing lava domes and associated moderate explosions and ashfalls. Eyewitness reports since 1354 (in the native Nahuatl and Spanish language translations) describe episodes of activity, while more recent and detailed written reports since 1500 document that about 16 small and 3 moderate eruptive episodes have occurred within the past 500 years, some of them probably involving dome growth-and-destruction processes similar to those 
of the current, ongoing activity (De la Cruz-Reyna et al. 1995; De la Cruz-Reyna and Tilling 2008).

\section{Ongoing Unrest, Eruptive Activity, and Volcanic Crisis}

Management of risk posed by volcanic unrest requires a comprehensive understanding of the natural phenomenon. In this regard, a sustained activity makes it particularly difficult to forecast the future activity and its consequences, because the commonly employed methodologies to recognize and assess the relevance of precursors of increased activity are obscured by the persistent low-to-medium level of activity. It is thus important to define and establish the context of the unrest to develop decision-making criteria.

Before the current activity, there was little public awareness outside the scientific community about Popocatépetl being an active and potentially hazardous volcano. The previous eruption of Popocatépetl was not a major event. It began in 1919, and the available descriptions of that activity (Friedländer 1921; Waitz 1921; Dr. Atl 1939) indicate that it consisted of a succession of dome emplacements and destructions, similar to the current eruptive episode, probably lasting until 1927. Then, after nearly 70 years of quiescence (except for a minor fumarolic event in 1947), Popocatépetl volcano reawakened in 1993 with increased fumarolic and seismic activity (De la Cruz-Reyna et al. 2008). By October 1994, this unrest further escalated, culminating with a series of moderately large phreatic explosions at the crater during the early hours of 21 December 1994. These explosions produced ashfalls on several towns to the east and northeast of the volcano, including the large city of Puebla.

At the time of the explosions, glaciers with an estimated total area of $0.54 \mathrm{~km}^{2}$ blanketed the northern flank of the cone, below the crater (Delgado-Granados 1997; Huggel and Delgado-Granados 2000). With the vivid memories of the 1985 Nevado del Ruiz disaster in the minds of authorities and scientists, nearly 25,000 people living in some of the most vulnerable towns located along the likely paths of pyroclastic flows and lahars were evacuated in the afternoon of 21 December as a precautionary measure. A week later, the eruptive activity decreased and its largely phreatic nature became better understood, the evacuated residents were allowed to return home. Ash emissions or protracted explosions consisting mostly of gas and steam with relatively low concentrations of ash and a characteristic emerging seismic signal were referred to as "exhalations." This type of relatively low-level activity persisted through 1995 and into early 1996, with decreasing intensity (De la Cruz-Reyna and Siebe 1997).

About a year later, seismicity and exhalation activity increased again, and on 26 March 1996 a lava dome was first observed growing on the crater floor. This dome was partially destroyed by an explosion on April 30, 1996, which propelled ejecta several kilometers into the sky and hot debris as far as $4 \mathrm{~km}$ and caused the only reported fatalities to date directly related to the Popocatépetl activity. Despite public warnings not to enter the $12 \mathrm{~km}$-radius restricted area around the mountain, five members of a sports club climbed to the summit crater rim to obtain good images and videos of the activity. These climbers were struck and killed by incandescent fragments during their descent, a few hundreds of meters downslope from the crater, as evidenced by the images recovered from their cameras. Dome-building activity resumed mid-March 1997 (GVN 1996, 1998). These 1996-1997 events marked the beginning of a series of dome growth-and-destruction cycles that have continued up until this writing. Although most of the explosions have been moderate, some of them have been large enough to produce pyroclastic flows (in 2001) and lahars (in 1997 and 2001; Capra et al. 2004).

In summary, the current eruptive episode to date has consisted of a succession of moderate-size eruptions, characteristic of Popocatépetl's activity since the 14th century (De la Cruz-Reyna et al. 1995). Nonetheless, given the huge population in the region potentially at risk, together with concerns about possible escalation 
of the ongoing eruptive activity to Plinian phases, or even worse a major sector collapse, the management of the "volcanic crisis" at Popocatépetl-already persisting for 20-plus yearsremains a major challenge for volcanologists, national and local Civil Protection authorities, and the threatened populations (De la Cruz-Reyna and Siebe 1997). From experience gained through 1997, involved scientists and decision-making authorities became increasingly convinced of the need to attain a more appropriate and uniform perception of the changing risk among all the stakeholders. Accordingly, in 1998 the Volcanic Traffic Light Alert System (VTLAS) was developed as a risk- communication protocol, hazards-warning system and response scheme specifically designed to manage the ongoing volcanic crisis at Popocatépetl more effectively (Fig. 3). A detailed description of VTLAS and its use are given by De la Cruz-Reyna and Tilling (2008), but we summarize below three salient points:

1. A level of activity of the volcano is defined by the PSC and translated into the most likely scenarios, describing them in specific terms, including time scales, names of threatened areas, etc. In general terms, these sets of scenarios may be grouped according to seven levels of response of the SINAPROC, which in turn are managed as phases within each of the Traffic light colors: two for Green, three for Yellow, and two for Red.

2. SINAPROC authorities translate the level of volcanic hazard defined by the PSC into one of three alert levels for the population (not of the volcano) that leave no room for uncertainty: Green, everything is fine; Yellow, you must be aware of the hazard and pay attention to any official announcements; and Red, you must leave the area according to the instructions given by the authorities.

3. All decisions involving mitigative actions are undertaken by the Civil Protection authorities according to the selected phase within the color level. It is important to emphasize that, in Mexico, the management of risks associated to natural phenomena is by law a responsibility assumed by the three levels of government: federal, state, and municipal. The Scientific Committees are officially appointed advisory groups of "more than 10 but less than 15 experts in the subject, which can emit opinions and recommendations about the origin, evolution and consequences of hazardous phenomena, aimed to technically induce decision making for prevention and mitigation to the population...", as stated by the Organization and Operation Manual of the National System of Civil Protection within the General Law of Civil Protection.

\section{Evolution of the Activity Influences Public Perception of Hazards}

Popocatépetl's historical volcanic activity has been dominated by an irregular, yet sustained dome-emplacement and destruction processes, which in turn have resulted in some significant fluctuations in the level of the summit crater floor. The floor, which was about $277 \mathrm{~m}$ deep in 1906 (Friedländer 1921), was raised almost 100 meters because of the accumulation of dome-forming products during the 1919-1927 eruptive episode (Gómez-Vázquez et al. 2016) The episode beginning in 1994 further accumulated enough material to raise the level of the crater floor to near the crater rim after the peak of activity in 2000-2001, thereby reducing the capacity of the crater walls to contain or reduce the range of potential pyroclastic flows. In fact, under these conditions an explosion occurring on January 22, 2001 produced pyroclastic flows that traveled about $4.5 \mathrm{~km}$ from the crater, affecting the glacier on its northeast slopes and triggering a lahar that reached the outer limits of Xalitzintla, one of the nearest villages (Sheridan et al. 2001; Capra et al. 2004; Macías and Siebe 2005). However, the general level of activity, as measured by exhalation-explosion events and dome-emplacement rates, significantly decreased after 2003, as the rate of dome destruction exceeded the rate of lava emplacement, causing 
Fig. 3 A poster designed for public offices showing the VTLAS

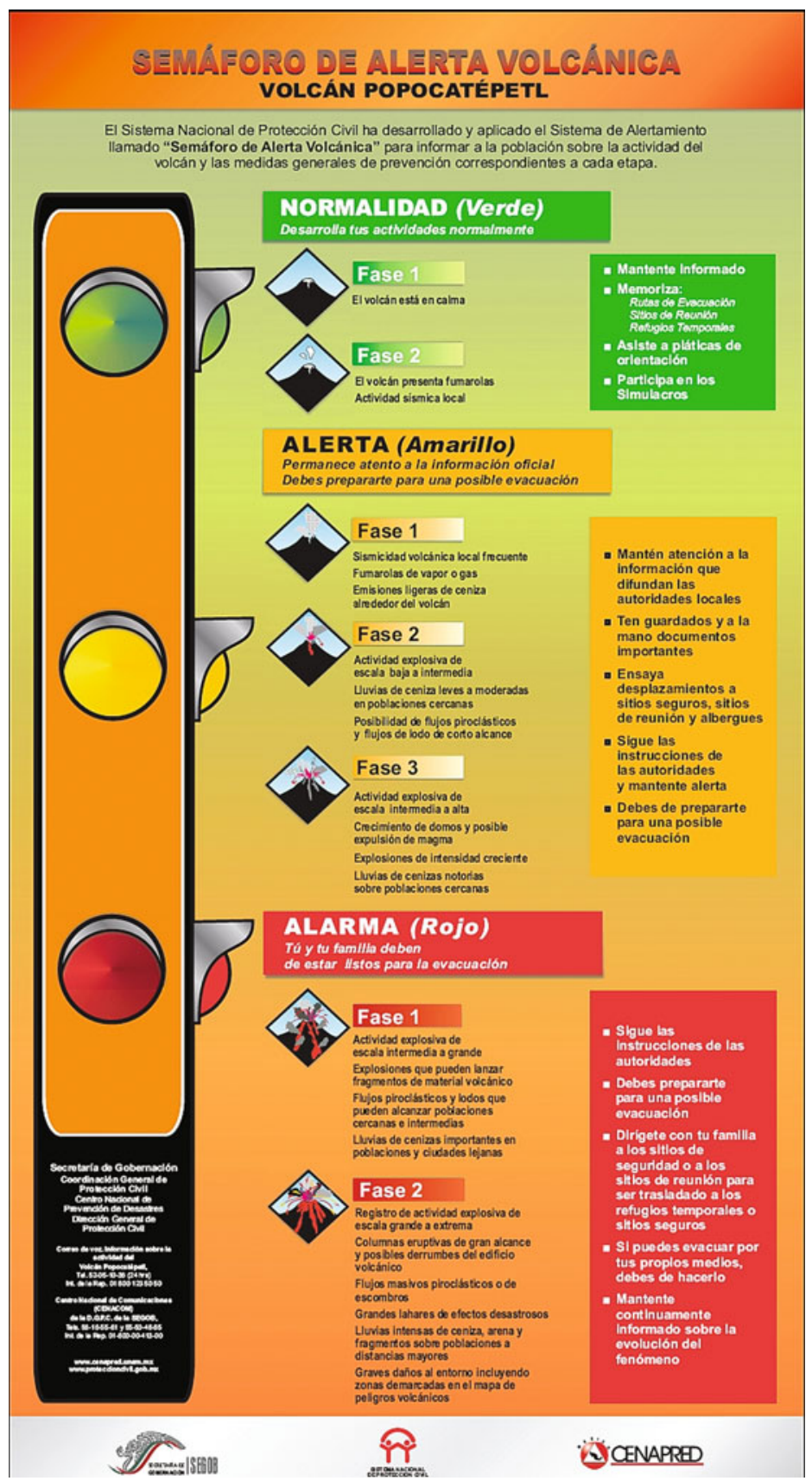

Figure 5 shows the evolution of seismicity during the period 1996-2014, as indicated by the fluctuations in total seismic energy release, a basic volcano-monitoring parameter expressed by RSAM values and their cumulative curve. RSAM (Real-time Seismic Amplitude Measurement) is a system that continuously samples the 
Fig. 4 View of

Popocatépetl's summit crater on 3 March 2015 showing that volcanic materials filling the crater had reached within $30 \mathrm{~m}$ below the lowest part of the rim (photograph downloaded from https:// www.whatsapp.com/). While providing useful information about the state of the volcano, this photograph was taken by a member of a group of adolescents who had climbed the summit area without authorization (see text for further discussion)

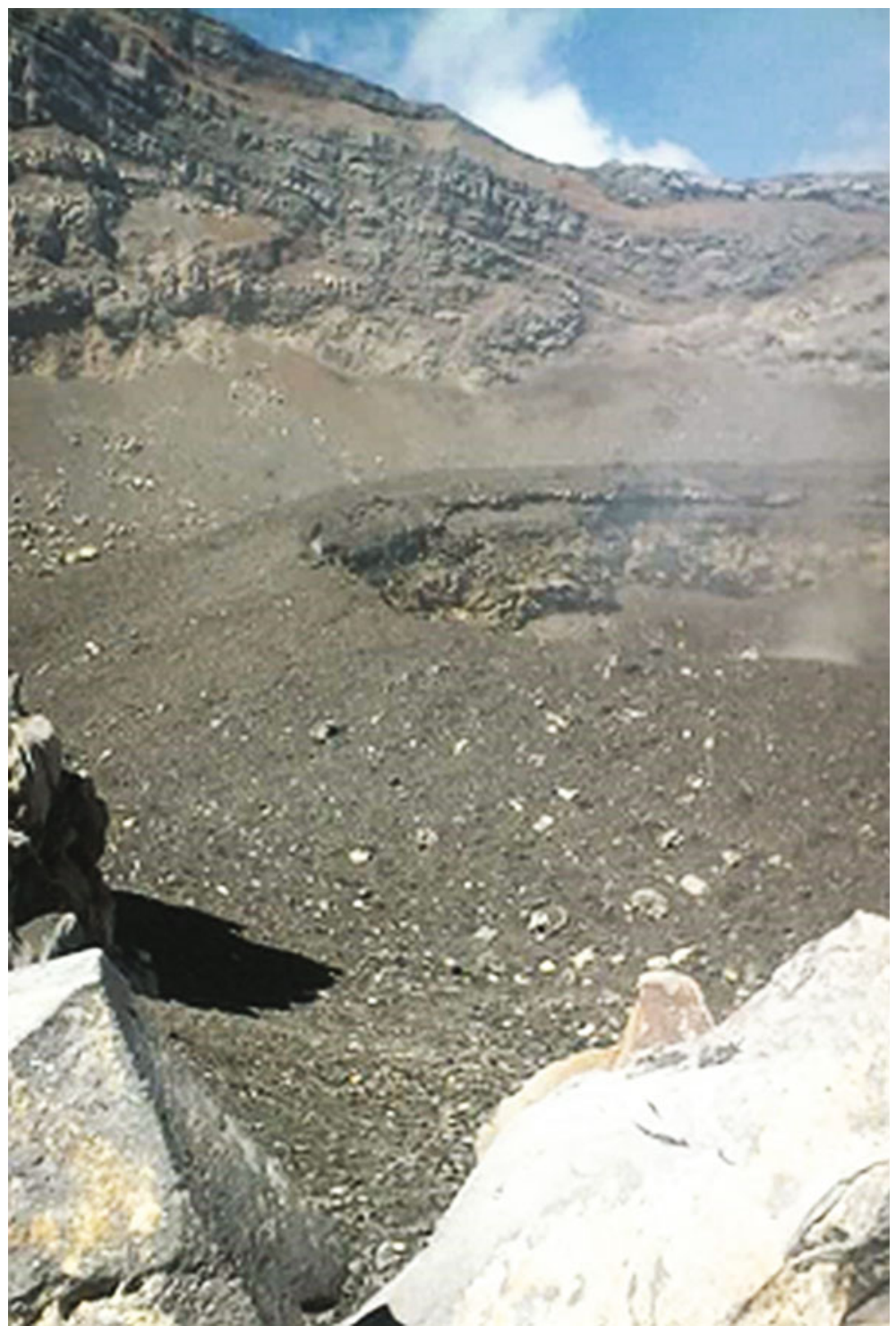

absolute amplitude of the seismometer signals (Murray and Endo 1989; Endo and Murray 1991). From RSAM data, the cumulative seismic energy released by the volcano provides a very good proxy of its vigor of eruptive activity, as it reflects the total seismic energy release from all sources: VTs, explosions, exhalations, tremors, etc. Figure 5 exhibits that the overall level of activity varied little between 1996 and early 2000 , with a weak increasing trend from the onset of the activity before sharply increasing in late 2000 and the start of 2001. Afterwards, the level of activity gradually decreased keeping a relatively low level until a new marked increase in RSAM counts in mid-2010. During the period 2003-2010, however, far fewer reports of visible volcanic manifestations - such as observed explosions, exhalations or lava accumulationinduced many people to believe that the eruptive activity perhaps was approaching its end, despite the seismic-monitoring data indicating otherwise. Expectedly, public interest in the volcano waned and perception of its hazards slowly started to dissipate. Yet, volcano monitoring and the 


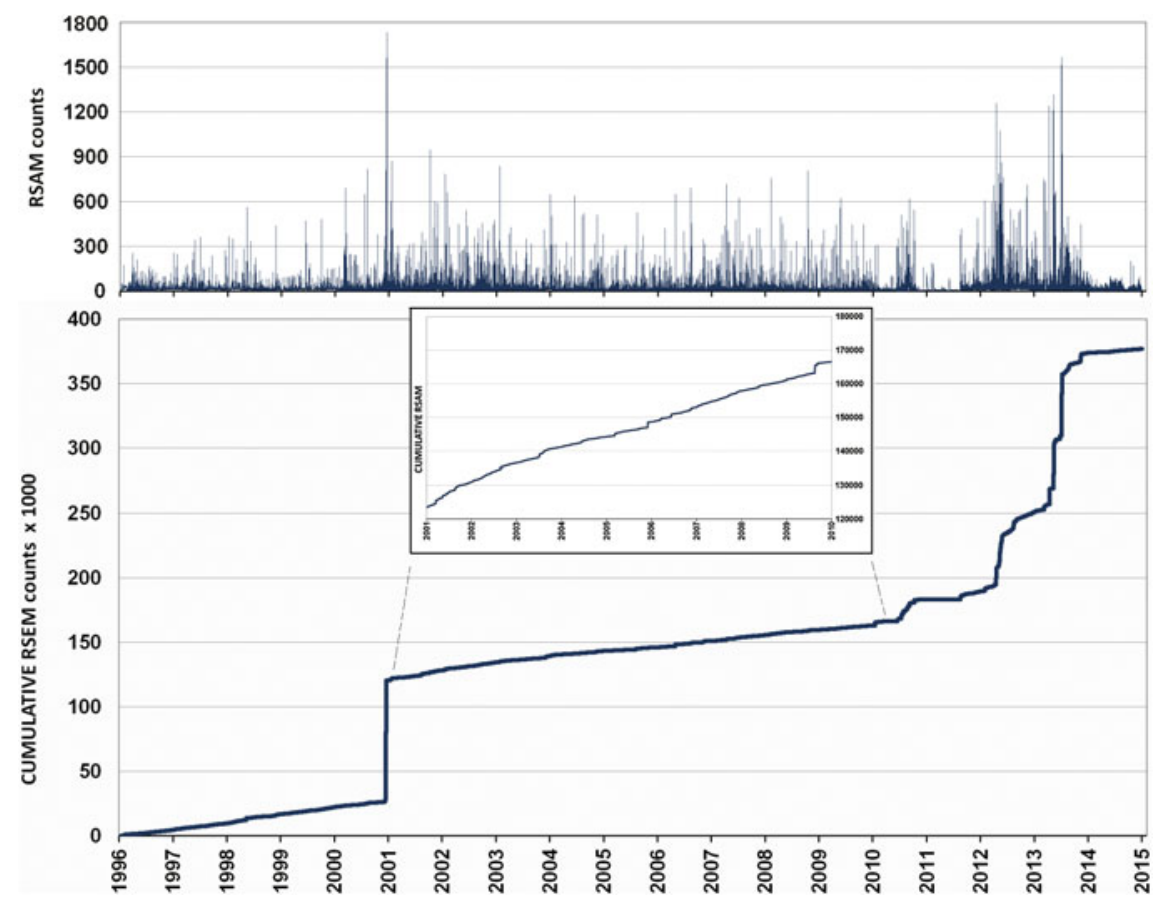

Fig. 5 Evolution of seismicity during the period 19962015, as recorded by the Chiquipixtle seismic station (PPX), located to the WSW of the crater, at a height of $3980 \mathrm{~m}$. asl. Above, each vertical bar represents a ten-minute RSAM average of the seismic signal amplitude sampled at a rate of 100 samples per second. Below, cumulative RSEM (sum of successive squared RSAM values, proportional to the total seismic energy detected

information about the volcano activity were never scaled down, as the daily reports on the volcano condition and the status of the VTLAS, which remained in Yellow, were published every day by CENAPRED in its website. Nevertheless, only when activity manifestations such as explosions, exhalations or persistent fumaroles become visible, the media massively reproduces such reports. The proliferation of social networks and fixed webcam sites, such as http://www. webcamsdemexico.com/ (with more than half a million followers), has made possible wide dissemination of information about the occurrences of even minor events, thereby improving in this way the persistence of awareness. by the monitoring station). In December 2000, the activity increased sharply, including recorded manifestations such as saturating harmonic tremors (see Fig. 6). This surge in seismic activity prompted a precautionary evacuation of towns exposed to pyroclastic and lahar flows. The seismic energy release since 2010 has been actually larger, but at a lower rates. The inset in the center shows a zoom of the waning RSEM in the period 2001-2010

\section{Development of Risk-Mitigation Strategies Since 1994}

Perhaps the main challenge in managing the response to the ongoing volcanic activity of Popocatépetl has been posed by its rather pedestrian, anti-climactic character, particularly during the 2003-2010 period. The initially impressive phreatic eruption of 1994 that sharply contrasted with the quietness of the previous 70 years prompted the frenzied making of a Popocatépetl's volcanic hazards map (Macías et al. 1995) in only a few months under high-stress conditions. This map - the first such for Popocatépetl specifically 
intended for use by civil authorities — was made with a general consensus of the involved Mexican and U.S. experts. The high-urgency 1994-95 scientific and governmental response, which also included the development of the VTLAS, then gradually declined until the onset of effusive magmatic activity in 1996. The VTLAS was set at Yellow for the population at the moment of its implementation in mid-1995. The slow decline of the ash-emission events, the direct source of public and authority awareness, was not much in agreement with the data from the volcano-monitoring instruments. The VTLAS thus remained in Yellow even when the volcano appeared to be in a relative state of rest. News media and the public started to joke about a "busted" traffic light. However, in March 1996, the emplacement of the first lava dome confirmed an ongoing level of eruptive activity, and thereby rekindled public and media interest and concern. Unlike the initial 1994 episode, the now much-improved monitoring data allowed a better understanding of the 1996 activity. Because the character of the dome -emplacement processes was effusive and confined within the summit crater, the PSC continued to recommend maintaining the VTLAS in Yellow, as the probabilities of pyroclastic flows or lahars were still low. It was at that time that some members of a sport clubs climbed to the crater rim. Tragically, this imprudent action resulted in the above-mentioned casualties caused by the first dome-destruction explosion, again rekindling the interest of public and media.

Dome-emplacement and destruction activity continued in the ensuing years with a somewhat increasing trend, but without exceeding the levels set by the scenarios marked by the VTLAS, so it continued in condition Yellow. However, the dome-destruction explosions in 1997, and particularly the $13 \mathrm{~km}$-high ash column of 30 June that caused ashfalls in Mexico City and impelled closing its airport for $12 \mathrm{~h}$, prompted changing the VTLAS to Red for a few hours. However, no evacuations of populations were ordered, thereby generating some confusion among people and authorities. Studies at other volcanoes (Solana et al. 2008) indicate that, although civil authorities are aware of the volcanic hazards, their understanding of how to respond during an emergency can be incomplete, and that understanding how people perceive risk is important for improving risk communication and reducing risk-associated conflicts (Haynes et al. 2008).

At this stage, the need of an embedded scale within the three-color alert levels designating the alert level of authorities became immediately evident; see De la Cruz-Reyna and Tilling (2008) for a detailed account of the VTLAS levels. The quick return to condition Yellow, as no evacuations were needed, again prompted the news media and public to joke about a "busted" traffic light. Public discussions on this subject, however, ultimately proved to be beneficial, because it helped to convey to the general public and many authorities that the color of the Traffic Light is not a description of the state of the volcano, but rather it is a description of the threat on people and thus reflects the state of awareness of individuals. Hence, the VTLAS remained in Yellow, although the phase, i.e., the level of alert for Civil Protection authorities, has changed several times.

The VTLAS was only temporarily set again in condition Red at the peak of intensity (i.e., rate of seismic energy release) of the entire eruptive episode during December 15-19, 2000. Unlike the 1997 event, the management of the December 2000 eruption was more efficient as lessons were learned from the 1997 experience. The colors and phases of the VTLAS, and a safety radius of $12 \mathrm{~km}$ around the crater, were then clearly defined by the PSC. This radius narrowly excluded the closest towns to the volcano. The Red-VTLAS was set on the basis of a $24-h$ forecast made by the PSC from the large amplitude of the volcanic tremor signals, and using results from a load-and-discharge time-predictable model consisting of a succession of episodes of variable intensity, in which the seismic energy released by a high intensity episode of activity is followed by a lower-intensity period with a duration proportional to the previous energy drop (see for example De la Cruz-Reyna 1991). The exclusion radius was then extended to $13 \mathrm{~km}$, and an evacuation of the towns within that radius was undertaken 


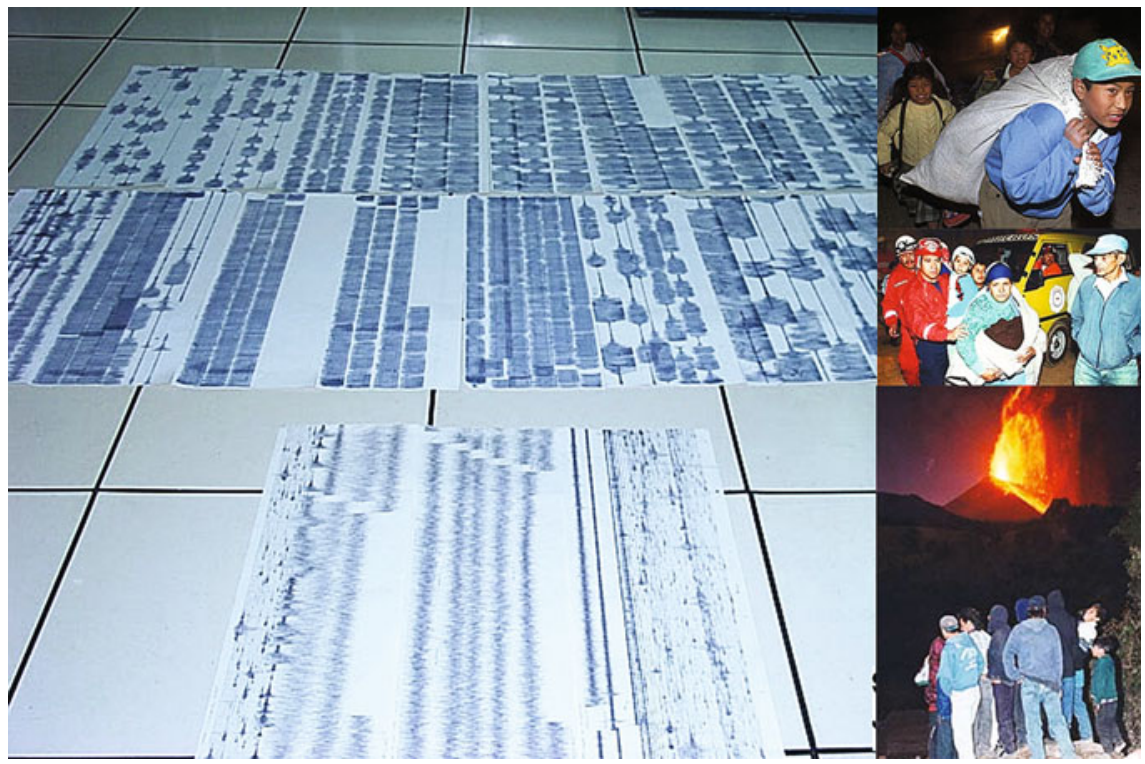

Fig. 6 Left Seismograms of the December 2000 activity (back), showing highly saturated recordings, compared with seismicity recorded for the largest previous eruptive event in June 1997 (front), which caused ashfall on

(Fig. 6). This precautionary action was taken because the dome-destroying eruptions ejected large amounts of hot debris onto the glacial ice that could induce localized melting, such that even minor pyroclastic flows could produce powerful lahars. One of the vexing difficulties in the management of the December 2000 response was a marked overreaction of authorities in some small towns slightly beyond the exclusion radius. Concerned that some nearby towns were being evacuated, these officials decided to order immediate evacuations, without waiting for confirmation of the National Security Committee. No criteria for the return of these people to their homes were defined at the time, and some evacuees remained up to 10 days in temporary shelters. The problems of overreaction and the lack of clear "return" criteria to lower the level of alert have not yet been solved (De la Cruz-Reyna et al. 2000).

The December 2000-January 2001 explosive activity marked a watershed in the evolution of the ongoing volcanic crisis at Popocatépetl. Before 2001, the accumulation rate of dome lavas and debris exceeded the rate of removal by explosive
Mexico City, obtained from the same CENAPRED monitoring station. Right Images of the evacuation and of evacuees watching the eruption from a safe distance (photographs courtesy of Associated Press)

activity. After a period of irregular activity lasting until 2003, that trend slowly reversed, and the main crater slowly began to recover some of its former capacity (Gómez-Vázquez et al. 2016). After 2003, a lower lava emplacement and explosion rates (shown as a diminishing slope of the cumulative RSEM counts in the inset of Fig. 5) prompted a reduction of the VTLAS phase from Y-3 to Y-2, and then to Y-1 in 2004, still maintaining however condition Yellow on affected populations. The slightly increased seismic activity in late 2005 and 2006 raised the VTLAS phase back to Y-2. Overall, between 2005 and 2009, the rate of dome-lava growth did not exceed the rate of debris removal by explosions and exhalations, so that the crater continued to deepen slightly. Explosive activity gradually increased again in mid-2010 and continued with minor fluctuations through 2011. On 20 November 2011, a powerful explosion ejected large ballistic blocks to distances of $4 \mathrm{~km}$; this explosion also generated a shock wave that was felt by some people as far away as $10 \mathrm{~km}$ from the volcano, but luckily with no damaging consequences. 
Fig. 7 The results of a telephone survey of 800 people, conducted on 19 April 2012, to gauge the general public's perceptions of the ongoing, but generally low level, activity of Popocatépetl. (Image from http:// kaleydoscopio.mx/)

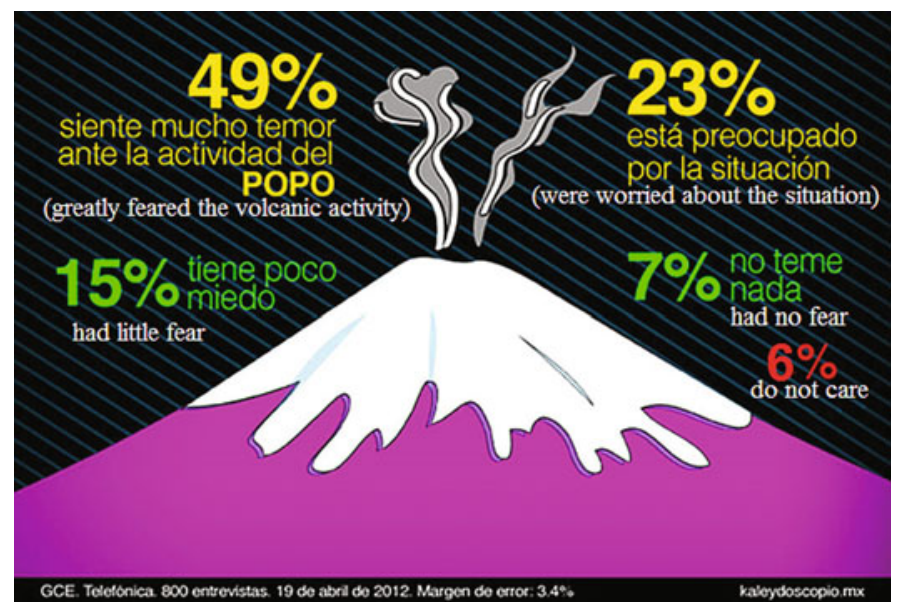

Since 2001, dome building, exhalations, and explosions have continued sporadically to the date of this writing (July 2016). Accordingly, this persistent, though irregular, activity has necessitated that the VTLAS remains for long times in condition Yellow, leading to some wearisomeness and complacency among the populace and some municipal authorities of towns near the volcano during protracted lull periods. However, no complacency existed among authorities at the federal level. During periods of relative inactivity, the PSC and the CP authorities discussed in depth the pros and cons of making the VTLAS more dynamic, particularly lowering it to Green during relative quiescences. However, after much debate, a strong argument finally gained consensus: Green conditions would immediately allow the occupation and/or reoccupation of previously restricted areas close to the limit of the National Park, and well within the exclusion radius of $11 \mathrm{~km}$. Then, should a new episode of more intense explosive activity arise, it would be much more difficult to evacuate people than it would be had the VTLAS remained in Yellow. Thus, it was decided to retain the current protocols, until there was solid evidence that the now two-decade-long eruptive episode had completely finished and the volcano had re-entered another long repose period.

The continuing, persistent moderate level activity of the volcano, together with the need to keep an intermediate level of alert among people and authorities, has generated an awkward situation that may well be called a "semi-crisis," which appears to be taken less seriously than a full-blown crisis among authorities and communities surrounding the volcano. The ambivalence of how this "semi-crisis" is viewed may be gleaned from the results of a telephone survey conducted in April 2012. Of the 800 people surveyed, $49 \%$ greatly feared the volcanic activity, 23\% were worried about the "situation", but the remaining $28 \%$ had little or no fear, or had no opinion (Fig. 7). Of continuing concern to the authorities, some people clearly do not perceive the volcano as a risk, as evidenced, for example, by the actions of a group of adolescents in March 2015. This group-numbering about 15 and all under the age of 18 - had climbed to Popocatépetl's summit crater five times, against government restrictions and apparently oblivious to dangers from possible volcanic activity during their ascents (https://www.youtube.com/watch? $\mathrm{v}=$ higZ7j980g8).

\section{Scientific Strategies and Scientific Challenges}

The main function of the Popocatépetl Scientific Committee (PSC) is to assess the hazards related to the activity of Popocatépetl volcano. From its earliest sessions in 1995, a methodology that proved to be efficient and practical was adopted. 
Sessions are chaired by a moderator, usually the director of CENAPRED, or a high authority from the National Autonomous University of Mexico (UNAM) or from the Ministry or Interior, and usually limited to $2 \mathrm{~h}$, unless a special situation requires more time. The sessions are split into three parts. In the initial one, the monitoring groups describe the recent observations, always in the same order: seismic, geodetic, visual, geochemical, and others (Fig. 8). Questions are allowed, but no discussions are permitted until the exposition of all the data is complete. In the second part, the members of the PSC discuss the observations and propose possible explanations of the observed data. This discussion is steered towards interpretations for which consensus seem to exist. Non-consensual matters are set aside to be discussed later elsewhere. In the third part, the PSC proposes the most likely scenarios based on the consensus of the previous discussions. When a small number of likely scenarios is agreed upon, the PSC summarizes the likely scenarios and makes recommendations to the Civil Protection (CP) authority based on all previous deliberations. This method, which is similar to the differential diagnosis used in medical science, has proved effective to make diagnostics and prognostics of the volcano activity, and to present them to $\mathrm{CP}$ as a list of the possible scenarios in a descending order of likelihood. We re-emphasize that the PSC does not set the level of the VTLAS, which is done by the CP authorities based on the PSC recommendations.

The main difficulties faced by the scientists of the PSC may be summarized in two different realms: firstly, the scientific and technical one related to understanding of volcanic processes and, secondly, the operational aspects in effectively communicating hazards information to the $\mathrm{CP}$ authorities, news media, and the affected populace. With regard to the former, apart from the typical instrumental and technological inadequacies and limitations in the amount and

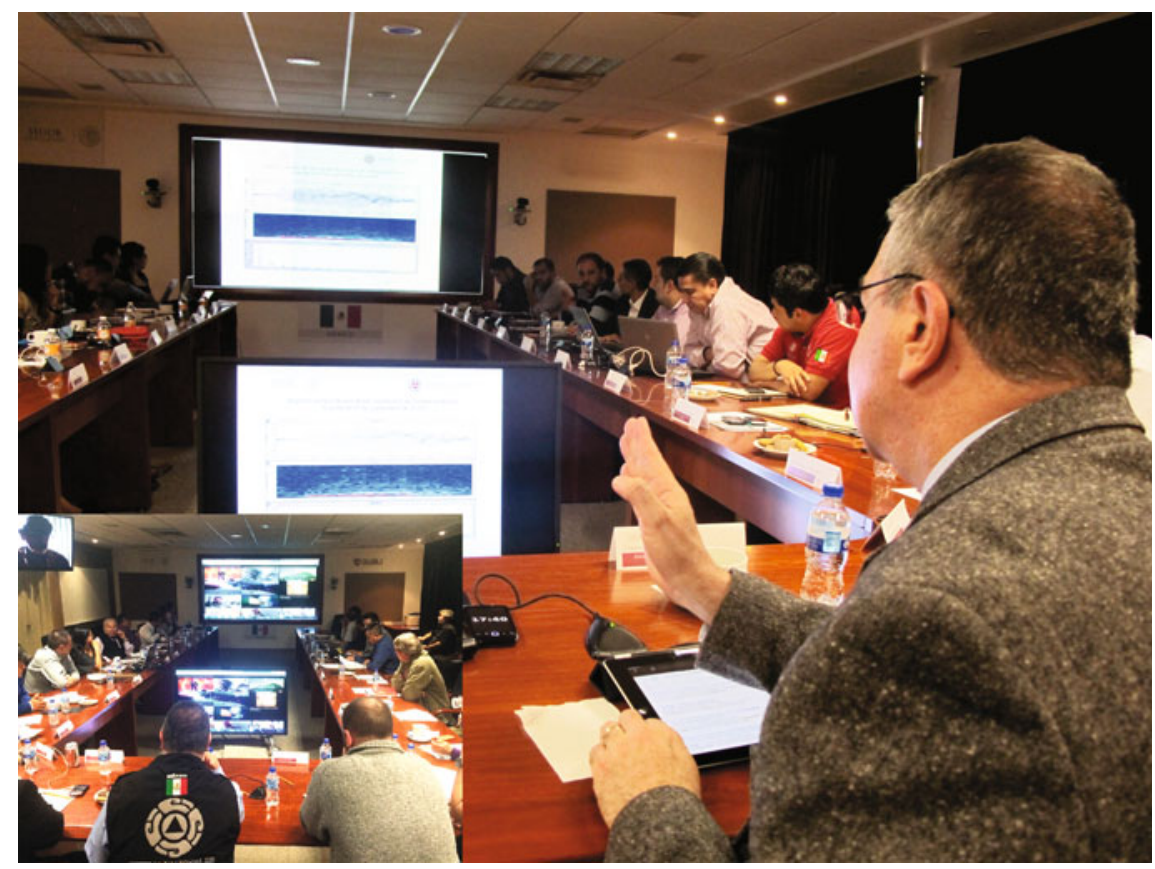

Fig. 8 A session of the PSC in progress in 2014, at which the relevance of changes in seismic spectrograms related to observed visible signs of volcanic activity is being discussed. The inset shows a session in 2015 at which the main subject was the policies to deal with people disregarding the security radius to climb Popocatépetl Volcano. All sessions of the PSC are recorded 
quality of monitoring data, an important issue has been the evolution of the precursors' meaning and possible implications. Specifically, what do the variations in precursory activity portend what the volcano might do next? During the initial years of the crisis at Popocatépetl, acquired experience allowed identification of clear precursors to explosions, such as harmonic tremors; repetitive short-duration, low-amplitude LP events (drumbeats); accelerated rate of RSAM counts, etc. However, and with no clear watershed (although it may be related to the change of eruptive regime in 2001-2003), in several instances such seismic signals were not necessarily followed by explosions. On the other hand, cumulative volcano-tectonic (VT) energy release, rate of dome growth, and VT appearing in specific locations seemed to have become more relevant precursors.

With regard to effective communications of hazards information, in addition to the general factors considered previously discussed, an additional recurrent hindrance during the Popocatépetl crisis has been the frequent changes of decision-making authorities over time scales shorter than the duration of the volcanic activity. Federal and state governments change every 6 years, so that within each period of administration the responsible $\mathrm{CP}$ authorities with whom the scientists interact may be replaced more than once. Thus, it is always necessary to train the new authorities in the communication process. Fortunately, in all cases, the communication of volcanic risk based on likely scenarios has made it possible to deal with this problem relatively easily.

Although the basic tools for scientific assessment of the hazards and systematic monitoring of the activity have not always been sufficient, CENAPRED has made, and is making, a major effort in maintaining the highest technological standards in the volcano-monitoring networks. In addition, a new volcanic-hazards map by a team of volcanologists at the Instituto de Geofísica, and other UNAM institutes has replaced the current one (Macías et al. 1995), which was prepared under rushed conditions with minimal data available at the time. The new hazards map considers a wealth of new geological information collated over the past 2 decades (in particular, extent of lahar inundation areas, magnitude and timing of past Plinian eruptions, ash dispersal data, etc.). The updated hazards map and assessment were released by CENAPRED in (2016). Participants in the current map include some of the authors of the 1995 map: Siebe, Macías, Capra, Delgado, and Martin del Pozzo, plus their associates (e.g., postdocs, students). The CP system provided a special fund (FOPREDEN. Disaster Prevention Fund) to finish the new map, although much of the new scientific data were obtained with research projects financed by CONACYT (Mexican National Science Council) and DGAPA (The UNAM fund to support major research projects).

\section{Concluding Remarks and Future Challenges}

The historical activity of Popocatépetl has been characterized by eruptive episodes of activity similar to the current one (1994-present). The relatively low magnitudes of the eruptions reported since the year 1500 have not left enough geological evidence to assess their evolution with time. Nonetheless, historical accounts (detailed in De la Cruz-Reyna et al. 1995, and summarized in De la Cruz-Reyna and Tilling 2008) suggest that the described events may correspond to the most visible manifestations (i.e., dome-destruction explosions) within long-duration episodes of successive dome emplacement and destruction. Without further evidence other than the general, and sometimes vague, wording of the reports, the events listed in De la Cruz-Reyna and Tilling (2008) may be grouped into about six of such episodes, as shown in Table 1.

No statistical analysis of Table 1 is attempted because of the subjective grouping of episodes. However, some hints may be gleaned from the inspection of the information summarized in the table. The current eruptive episode is not anomalously long, and within the range of 
Table 1 Grouping of the 19 known historical eruptions of Popocatépetl volcano (De la Cruz-Reyna and Tilling 2008) into six long-duration episodes involving successive dome-emplacements and dome-destruction explosions, interspersed with long periods of quiescence

\begin{tabular}{l|l|l|l}
\hline Period & $\begin{array}{l}\text { Estimated minimum } \\
\text { duration (y) }\end{array}$ & $\begin{array}{l}\text { Estimated lapse until next } \\
\text { episode (y) }\end{array}$ & $\begin{array}{l}\text { VEI range of eruptions in the } \\
\text { period }\end{array}$ \\
\hline $1512-1548$ & 36 & 23 & $2-3$ \\
\hline $1571-1592$ & 21 & 50 & 2 \\
\hline $1642-1665$ & 23 & 32 & $2-3$ \\
\hline $1697-1720$ & 23 & 199 & $1-2$ \\
\hline $1919-1927$ & 8 & 67 & 2 \\
\hline $1994-$ present & $>20$ & $?$ & $2-3$ \\
\hline
\end{tabular}

durations of previous historical episodes. Moreover, the expected lapse to a future episode does not seem to be correlated with the duration of the previous episode or the duration of the previous lapse. Unfortunately, the historical information precludes any reliable means to forecast the precise time and explosivity of the next eruptive episode after the current one ends. The possibility that the next episode could involve a destructive Plinian phase cannot be ruled out; Plinian eruptions have occurred in the geologic past, with a mean return period of about 1500 years (Siebe et al 1996; Mendoza-Rosas and De la Cruz-Reyna 2008). A formidable challenge for scientists and the civil authorities in anticipating Popocatépetl's future behavior is to address this question: if the current already-long episode continues as a semi-crisis for a lot more time, what are the best options to counteract the wearisomeness and indifference of some of the stakeholders? There are no easy answers. Suggestions have been made to replace the VTLAS by another alert system. Apart from the confusion that a new, untested system may induce in the large population involved, it may not help necessarily solve the problem, as the dullness of the situation is not caused by the alert system, but instead by the pauses characterized by the absence of major explosions or any other visible expressions of increased volcanic vigor. A positive aspect is that when a highly visible event such as a moderate explosion occurs on a clear day, the public's volcano awareness seems to recover almost instantly, as has been the case since 2011. Figure 9 illustrates the positive reaction of the news media and the $\mathrm{CP}$ preparations in response to a raise in the alert level of the VTLAS to Yellow Phase 3.

Identifying the end of the current, relatively minor eruptive episode or the possible precursors of a much more explosive activity poses other major challenges. In particular, as seismic records constitute the dominant volcano-monitoring data for Popocatépetl and most other active volcanoes, it is crucial to better understand the empirical relationships between the seismic signals recorded since 1994 and the nature and vigor of the observed volcanic activity preceding, during, and following the seismicity. Physical models then can be developed to explain the source of the diverse seismic signals. Such method is inherently non-unique, and in some cases the ambiguity of the possible causes may lead to inadequate or even incorrect assessment of the hazards. Reduction of such levels of non-uniqueness based on integral analysis of different types of geophysical and geochemical data is a critical need to be fulfilled in the future with additional data and more diagnostic analytical methodologies. In the meanwhile, however, some pragmatic actions must be implemented. That it is why the Popocatépetl Scientific Committee, in attempting to reduce such a complex problem, has strongly emphasized the consensual approach in its deliberations. In a broader context, experience gained over recent decades at volcanoes worldwide indicates a sobering reality: despite the considerable advances in volcano-monitoring techniques, except for 


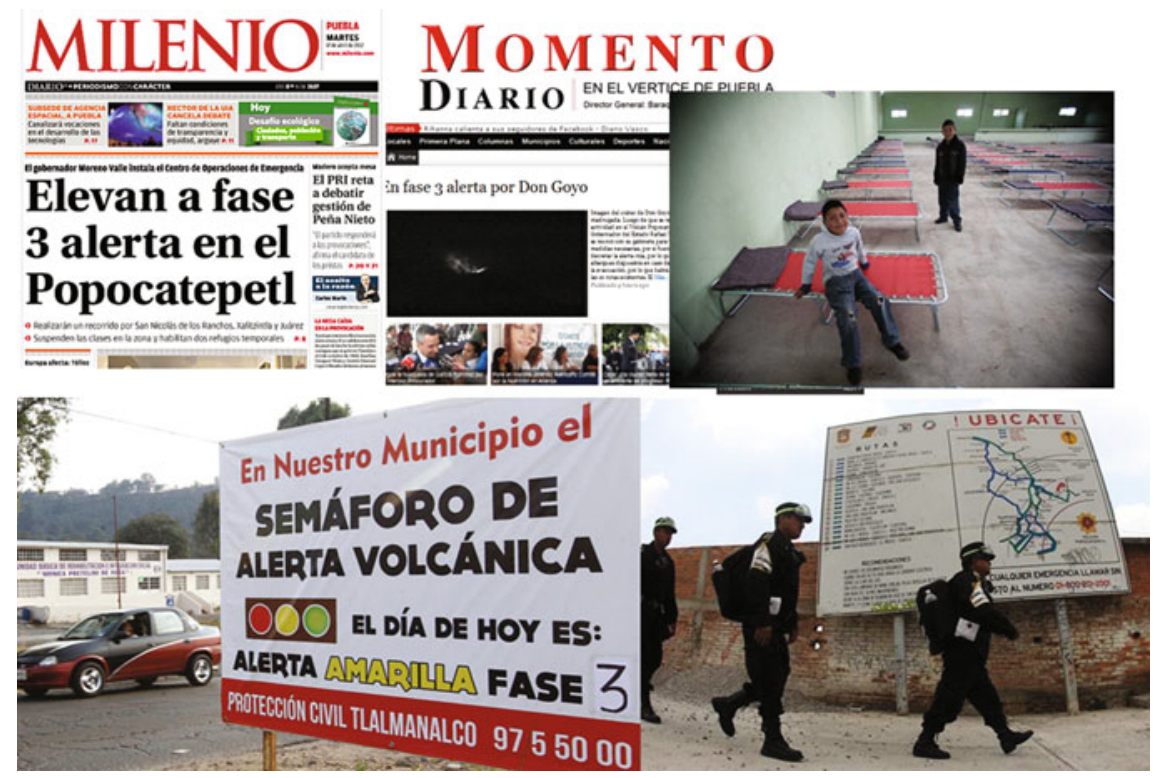

Fig. 9 Front pages of the Puebla City news media announcing the raise in alert level to Yellow Phase 3 in the VTLAS. This phase requires having emergency shelters

very rare exceptions, current state-of-the-art volcanology still lacks a routine, reliable capability to always correctly interpret a volcano's precursory signals and to accurately predict the outcomes of volcano unrest (e.g., Tilling 2014).

Maintaining a continuous flow of up-to-date information to the public about volcanic activity, hazards, and risk reduction seems to be the best and most practical solution to minimize the weariness and indifference that at times develop among the authorities and populations at risk during lulls of visible activity. In this regard, the daily posting of the activity reports of Popocatépetl on the CENAPED website (http://www.cenapred.gob. $\mathrm{mx} /$ reportes Volcan/BuscarReportesVolcan?opt Busqueda=1) apparently has been quite effective. This, together with the exponentially growing influence of fixed webcam sites and social media networks, has greatly increased public awareness of the occurrence of even minor events at Popocatépetl and other volcanoes in Mexico or ready (upper right), and CP personnel mobilized to carry out a possible evacuation (lower right)

elsewhere. Nonetheless, we recognize that the influence of user-generated social media reporting needs to be regarded with caution, because there is no assurance of the accuracy of the content of the transmitted information. Although most reports and comments diffused via social media are generally informative, at times scientifically unsupported remarks and predictions are also included, thereby contributing to possible confusion and generating a negative impact on the general awareness. To deal with this problem, SINAPROC opened a twitter account to spread reliable information. Dealing with modern-day modes of information dissemination poses another major challenge for all those involved in the management of volcanic risk.

Acknowledgements This research has been partially supported by the UNAM-DGAPA-PAPIIT project IN-106312. We wish to express our appreciation to Jose Luis Macías and an anonymous reviewer for helpful constructive reviews of an earlier version of this paper. 


\section{References}

Boudal C, Robin C (1989) Volcán Popocatépetl: recent eruptive history, and potential hazards and risks in future eruptions. In: Latter JH (ed) Volcanic hazards. IAVCEI proceedings in volcanology. Springer, Berlin, pp 110-128

Capra L, Poblete MA, Alvarado R (2004) The 1997 and 2001 lahars of Popocatépetl volcano (Central Mexico): textural and sedimentological constraints on their origin and hazards. J Volcanol Geoth Res 131 (3):351-369

CENAPRED (2016) http://www.cenapred.gob.mx/es/Publi caciones/archivos/357-CARTELMAPASDEPELIGRO SDELVOLCNPOPOCATPETL.PDF; http://www.cena pred.gob.mx/es/Publicaciones/archivos/270-INFOGRA FAPOPOCATPETL-FLUJOSPIROCLSTICOS.PDF; http://www.cenapred.gob.mx/es/Publicaciones/archivos /270-INFOGRAFAPOPOCATPETL-LAHARES.PDF; http://www.cenapred.gob.mx/es/Publicaciones/archivos /270-INFOGRAFAPOPOCATPETL-DISPERSINDEC ENIZA.PDF; http://www.cenapred.gob.mx/es/Publica ciones/archivos/270-INFOGRAFAPOPOCATPETL-A VALANCHAS.PDF; http://www.cenapred.gob.mx/es/ Publicaciones/archivos/270-INFOGRAFAPOPOCATP ETL-CADADEBALSTICOS.PDF; http://www.cenapr ed.gob.mx/es/Publicaciones/archivos/270-INFOGRAF APOPOCATPETL-LAVAS.PDF; http://www.cenapr ed.gob.mx/es/Publicaciones/archivos/270-INFOGRAFA POPOCATPETL-SEMFORODEALERTAVOLCNICA. PDF

De la Cruz-Reyna S (1991) Poisson-distributed patterns of explosive eruptive activity. Bull Volcanol 54:57-67

De la Cruz-Reyna S, Siebe C (1997) The giant Popocatepetl stirs. Nature 388(6639):227

De la Cruz-Reyna S, Quezada JL, Peña C, Zepeda O, Sánchez T (1995) Historia de la actividad del Popocatépetl (1354-1995). Volcán Popocatépetl, Estudios Realizados Durante la Crisis de 1994-1995. CENAPRED-UNAM, México DF, pp 3-22

De la Cruz-Reyna S, Meli RP, Quaas RW (2000) Volcanic crises management. Encyclopedia of Volcanoes. Academic Press, San Diego, pp 1199-1214

De la Cruz-Reyna S, Tilling RI (2008) Scientific and public responses to the ongoing volcanic crisis at Popocatépetl Volcano, Mexico: importance of an effective hazards-warning system. J Volcanol Geoth Res 170:121-134. doi:10.1016/j.jvolgeores.2007.09.002

De la Cruz-Reyna S, Yokoyama I, Martínez-Bringas A, Ramos E (2008) Precursory Seismicity of the 1994 Eruption of Popocatépetl Volcano, Central Mexico. Bull Volcanol 70(6):753-767. doi:10.1007/s00445008-0195-0

Delgado-Granados H (1997) The glaciers of Popocatépetl volcano (Mexico): Changes and causes. Quatern Int 43-44:53-60. doi:10.1016/S1040-6182(97)00020-7

Dr Atl (Gerardo Murillo) (1939) Volcanes de México, vol I. La Actividad del Popocatépetl, Editorial Polis, México
Endo ET, Murray TL (1991) Real-time seismic amplitude measurement system (RSAM): a volcano monitoring and prediction tool. Bull Volc 53:533-545

Fearnley CJ (2013) Assigning a volcano alert level: negotiating uncertainty, risk, and complexity in decision-making processes. Environ Plann A 45:1891-1911

Fiske RS (1984) Volcanologists, journalists, and the concerned local public: a tale of two crises in the eastern Caribbean. Explosive volcanism: interception, evolution, and hazard. National Academy Press, Washington, DC, pp 170-176

Friedländer I (1921) La erupción del Popocatépetl. Memorias Sociedad Científica Antonio Alzate 40:219-227

Gómez-Vázquez A, De la Cruz-Reyna S, Mendoza-Rosas AT (2016) The ongoing dome emplacement and destruction cyclic process at Popocatépetl volcano, Central Mexico. Bull Volcanol 78(9):1-15. doi:10. 1007/s00445-016-1054-Z

GVN (1996) Global Volcanism Network, Smithsonian Institute Bulletin 21(8)

GVN (1998) Global Volcanism Network, Smithsonian Institute Bulletin 23(2)

Haynes K, Barclay J, Pidgeon N (2008) Whose reality counts? Factors affecting the perception of volcanic risk. J Volcanol Geoth Res 172:259-272

Huggel C, Delgado-Granados H (2000) Glacier monitoring at Popocatépetl Volcano, México: glacier shrinkage and possible causes. In: Hegg C, Vonder Muehll D (eds) Beiträge zur Geomorphologie. Proceedings Fachtagung der Schweizerischen Geomorphologischen Gesellschaft, Bramois, WSL Birmensdorf, pp 97-106

Macías JL, Carrasco-Nuñez G, Delgado-Granados H, Martin de Pozzo AL, Siebe C, Hoblitt RP, Sheridan FM, Tilling RI (1995) Mapa de peligros del Volcán Popocatépetl: Instituto de Geofísica, UNAM, México, DF (scale 1: 250,000)

Macías JL, Siebe C (2005) Popocatépetl's crater filled to the brim: significance for hazard evaluation. J Volcanol Geoth Res 141:327-330

Mendoza-Rosas AT, De la Cruz-Reyna S (2008) A statistical method linking geological and historical eruption time series for volcanic hazard estimations: applications to active polygenetic volcanoes. J Volcanol Geoth Res 176:277-290. doi:10.1016/j. jvolgeores.2008.04.005

Murray TL, Endo ET (1989) A real-time seismic amplitude measurement system (RSAM). US Geol Surv Open-File Rep 89-684:1-21

Peterson DW (1986) Volcanoes: Tectonic setting and impact on society. In: Active tectonics, Geophysics Study Committee, National Research Council: Washington, DC, National Academy Press, pp 231-246

Peterson DW (1988) Volcanic hazards and public response. J Geophys Res 93:4161-4170

Peterson DW, Tilling RI (1993) Interactions between scientists, civil authorities, and the public at hazardous volcanoes. In: Kilburn CRJ, Luongo G (eds) Monitoring active lavas. UCL Press, London, pp 339-365 
Potter SH, Jolly GE, Neall VE, Johnson DM, Scott BJ (2014) Communicating the status of volcanic activity: revising New Zealand's volcanic alert level system. J Appl Volcanol 3:13. doi:10.1186/s13617-0140013-7

Robin C, Boudal C (1987) A gigantic Bezymianny-type event at the beginning of modern volcano Popocatépetl. J Volcanol Geotherm Res 31:115-130

Sheridan MF, Hubbard B, Bursik MI, Siebe C, Abrams M, Macías JL, Delgado GH (2001) Short-term potential volcanic hazards at Popocatépetl, Mexico. EOS Trans Am Geophys Union 82(16):187-189

Siebe C, Abrams M, Macías JL (1995) Derrumbes Gigantes, Depósitos de Avalancha de Escombros y Edad del Actual Cono del Volcán Popocatépetl. Volcán Popocatépetl, Estudios Realizados Durante la Crisis de 1994-1995. CENAPRED-UNAM, México, pp 195-220

Siebe C, Abrams M, Macías JL, Obenholzner J (1996) Repeated volcanic disasters in pre-Hispanic time at Popocatépetl, Central Mexico. Past key to the future? Geology 24:399-402

Open Access This chapter is licensed under the terms of the Creative Commons Attribution 4.0 International License (http://creativecommons.org/licenses/by/4.0/), which permits use, sharing, adaptation, distribution and reproduction in any medium or format, as long as you give appropriate credit to the original author(s) and the source, provide a link to the Creative Commons license and indicate if changes were made.
Siebe C, Macías JL (2004) Volcanic hazards in the Mexico City metropolitan area from eruptions of Popocatépetl, Nevado de Toluca, and Jocotitlán stratovolcanes and monogenetic scoria cones in the Sierra Chichinautzin. Volcanic Field guide, Penrose Conf. Neogene-Quaternary Continental margin Volcanism. Geol Soc Am, pp 1-77

Solana MC, Kilburn CRJ, Rolandi G (2008) Communicating eruption and hazard forecasts on Vesuvius, Southern Italy. J Volcanol Geoth Res 172:308-314

Tilling RI (1989) Volcanic hazards and their mitigationProgress and problems. Rev Geophys 27:237-269

Tilling RI (2014) Volcano hazards and early warning. In: Meyers RA (ed) Encyclopedia of complexity and systems science. Springer, New York, 19 pp. doi:10. 1007/978-3-642-27737-5_581-2

Voight B (1990) The 1985 Nevado del Ruiz volcano catastrophe: anatomy and retrospection. J Volcanol Geoth Res 44(3):349-386

Waitz P (1921) La nueva actividad y el estado actual del Popocatépetl. Memorias Sociedad Científica Antonio Alzate 37:295-313

The images or other third party material in this chapter are included in the chapter's Creative Commons license, unless indicated otherwise in a credit line to the material. If material is not included in the chapter's Creative Commons license and your intended use is not permitted by statutory regulation or exceeds the permitted use, you will need to obtain permission directly from the copyright holder. 